\title{
Massive Open Online Courses Model with Self-directed Learning to Enhance Digital Literacy Skills
}

\author{
https://doi.org/10.3991/ijep.v11i5.22461 \\ Pinanta Chatwattana \\ King Mongkut's University of Technology North Bangkok, Bangkok, Thailand \\ pinanta.cecit.kmutnb.ac.th
}

\begin{abstract}
The Massive Open Online Courses with Self-Directed Learning model (SDL MOOCs model) was developed by researchers as a tool to promote learning outside the classroom for digital age learners. The concept is based on the combination of new technologies and teaching methods in order to create new ideas and innovations that can enhance learning for modern learners and, at the same time, respond directly to their learning experiences. Thus, instructors are responsible for organizing the environment and creating learner-friendly learning materials using existing technology, which can lead to a digital university learning society. The contributions of this article are: 1) to synthesize the conceptual framework of the SDL MOOCs model, 2) to develop the SDL MOOCs model, 3 ) to develop instructional processes with self-directed learning to enhance digital literacy skills (SDL process), and 4) to study the results of developing the SDL MOOCs model. The suitability of the SDL MOOCs model was assessed by 15 experts with extensive experience in the fields of online education design and development, computer science and information and communication technologies for education. The results of this research show that: 1) the SDL MOOCs model consists of 4 main elements (input factors, instructional process, output, and feedback), 2) the SDL process consists of 4 stages (preparation, web-based self-directed learning, post-testing, and certificate approval), and 3) the developmental adequacy of the SDL MOOCs model is at a very high level.
\end{abstract}

Keywords-massive open online courses, self-directed learning, digital literacy skills, digital university

\section{$1 \quad$ Introduction}

Innovative teaching methods of modern university teachers in the Era 4.0 are so important that modern teachers should pay attention to them and apply them these days. The current study aims to assess the overall advancement of research on digital technologies in Education 4.0. The main agenda is to find the direction and improvement of research related to the educational structure and change in the learning process of digital technologies. The recent development of digital technologies in many fields is prompting researchers to improve the quality of instruction by using these resources [1]. The Office of the Higher Education Commission (OHEC), Ministry of Education, 
in collaboration with the Office of the Permanent Secretary of the Ministry of Information and Communication Technology, has set up a project to develop Thai e-universities and is pioneering the development of a central system for Thailand's massive open online courses (MOOCs). Thailand's Massive Open Online Courses or Thai MOOCs, which will be used as an information technology architecture to host the "Lifelong Learning Space", which should promote self-learning [2]. At the same time, it will greatly improve the quality of social services, especially in the field of education. The exchange of knowledge, interactivity through social networks and the simultaneous consumption of multiple media channels allow Thai people to have unlimited access to information [3].

Massive Open Online Courses (MOOCs), or open public education system [4], are the format used to present a variety of lessons on different topics via the Internet network; thus, learners must register and then learn said lessons online via websites and web applications. MOOC content is produced primarily for teaching large groups of people, rather than specific content intended for classroom teaching that requires analysis of individual learners. Marrhich et al [5] mentioned the benefits of integrating MOOCs into an academic setting, including convenience, flexibility, accessibility, and increased completion rates. In addition, MOOCs provide learners with access to challenging courses

Self-directed learning (SDL) is a popular form of learning today, as information technology plays an important role in the learning of new generation learners. This form of learning emphasizes active learning through media and information technology. This form of learning emphasizes active learning through media and information technology in order to encourage learners to engage in self-directed learning experiences. Learners are also expected to develop more skills and be able to make their own learning plans, self-study, search for learning resources, and assess their learning outcomes on their own, with the help and support of instructional activities [6].

The fourth industrial revolution is driving a paradigm shift in educational policies and reforms in many countries. Developed nations are steadily adapting to technological change, filling the skills gap required, and opening doors to new resources [7]. Digital transformation is occurring in all fields, including higher education, bringing new challenges and opportunities for higher education development [8]. Digital literacy skills are associated with the understanding and application of digital technologies that encourage learners to develop lifelong learning. These skills should also enable the creation of a learning society based on the application of information technologies. In addition, digital literacy skills are seen as the 21 st century skills needed by learners. Creating new knowledge is at the heart of all basic literacies. Similarly, generating new information digitally by adapting, applying, designing, inventing, or writing information is also central to digital literacy [9].

According to the above principles and reasons, the researcher has the idea of developing the model of massive open online courses with self-directed learning to enhance digital literacy skills (SDL MOOCs model) as a guideline to further develop the MOOCs system with self-directed learning to promote online learning outside the classroom through web applications. In addition, learners are expected to be self-directed, 
which responds to student-centered learning policies and lifelong learning in Education 4.0.

Specifically, this article makes the following four contributions:

1. A comprehensive synthesis of the conceptual framework of the massive open online course model with self-directed learning to enhance digital literacy skills.

2. The development and implementation of a massive open online course model with self-directed learning to enhance digital literacy skills.

3. Implementing instructional processes with self-directed learning to enhance digital literacy skills.

4. A discussion of the results of developing the massive open online course model and teaching processes with self-directed learning to enhance digital literacy skills.

The structure of this article is as follows. Section 2 presents the methodological aspects of the study. Section 3 presents the main results and discusses the relevance of the proposed approach. Section 4 gives the main conclusions of this work, as well as some research perspectives.

\section{Research methodology}

This research concerns the development of a model of massive open online courses (MOOCs) with self-directed learning (SDL) to enhance digital literacy skills. The development concept presented here is mainly based on the approach and design of the ADDIE instructional system model [10]. Furthermore, the theories of MOOCs and selfdirected learning are applied in said design and development.

\subsection{Population}

The population for this research includes the 15 experts who have experience in the areas of web-based instructional design and development, computer science, and information and communication technologies for education.

\subsection{Data collection and analysis}

In developing the model of MOOCs with SDL to enhance digital literacy skills in digital universities, the researchers relied on the following tools for development and data collection: (1) the developed model of massive open online courses with self-directed learning, (2) the teaching processes with self-directed learning to enhance digital literacy skills (SDL process), (3) the design adequacy evaluation form of the developed model of massive open online courses, consisting of scoring questions (5 levels), and (4) the Design Adequacy Assessment Form for Developed Instructional Processes with Self-Directed Learning to enhance Digital Literacy Skills, consisting of scoring questions (5 levels). Statistics used for data analysis include mean (Mean) and standard deviation (SD). 


\subsection{Design and methodology}

As shown in Figure 1, the methodology of this research is divided into 4 stages.

At the first stage, the researcher studied the theories, articles, and literatures related to instructional system [10-12], massive open online courses [4, 13-15], self-directed learning [6, 16], digital literacy skills [9, 17-19], achievement, and satisfaction. After that, the relevant theories were analyzed and synthesized in order to find out the correlation of the theories above to identify the conceptual framework of research.

At the second stage, the researcher designed the structure and elements of the open online courses model based on the concepts of instructional system design that consists of systematic elements, processes and steps (system approach) [10-12], combined with instructional elements of massive open online courses [4, 13-15].

At the third stage, it is concerning the design and development of instructional processes with self-directed learning to enhance digital literacy skills, which is based on the theories of self-directed learning $[6,16]$. These instructional processes would be used as a prototype for further application in the system of open online courses (SDL MOOCs system), which would be further developed.

At the fourth stage, this is the stage that is related to the study of suitability on the development of the SDL MOOCs model and instructional processes with self-directed learning to enhance digital literacy skills (SDL Process). The study of suitability herein was conducted by the 15 experts specialized in the fields of design and development of web-based instruction, computer science, and information and communication technology for education. The criteria for data analysis are on the basis of interpretation of Kanasutra [20].

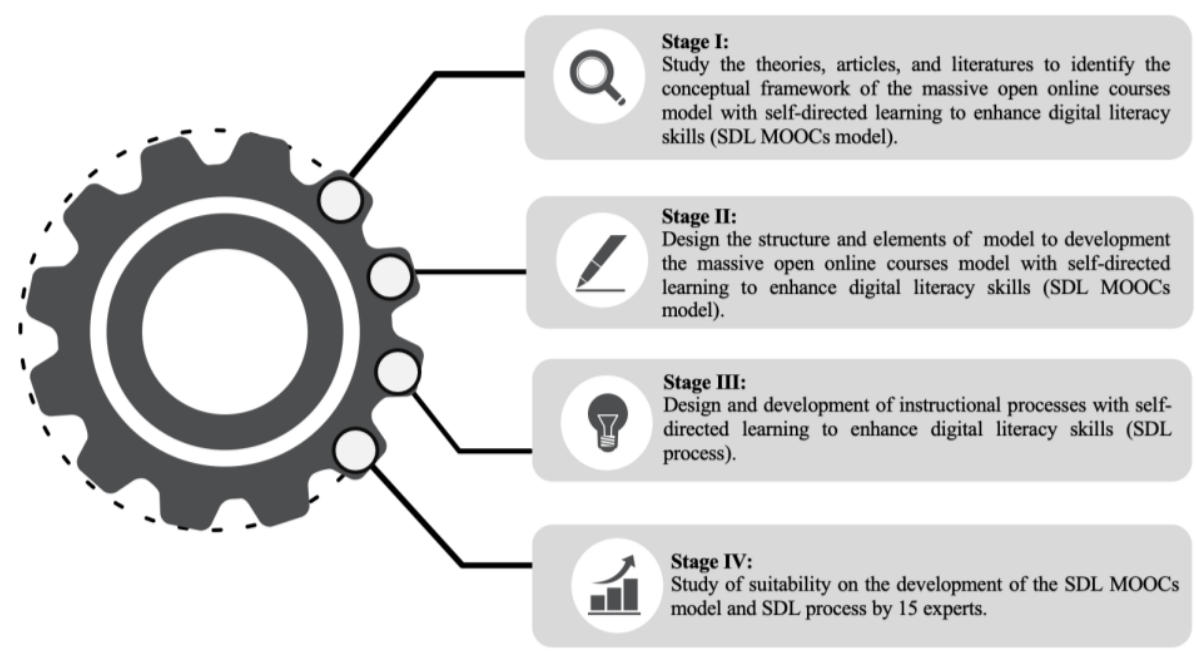

Fig. 1. Research methodology 


\section{Main results and discussion}

\subsection{Relevant theories to be used as a conceptual framework for the model of MOOCs with SDL to enhance digital literacy skills}

Correlation between educational system theories and the development of the SDL MOOCs model. The educational system is considered as a presentation of concepts applied to the management of different elements in such a way that they are correlated to each other and lead to the desired goal. This requires the ability to distinguish said essential elements and manage their correlation so that they can promote each other in an orderly manner [10-11]. The design of an educational system consists of four elements: (1) the input, which refers to the elements involved in the introduction of something into the system, (2) the process, which is the management of the correlation of the elements within the system so that they correlate with each other and pave the way for the achievement of the objective, (3) the output, which is the result of the work process, and (4) the feedback, which is the information obtained by analyzing the relationship between the output and the objectives, which will help to improve the process and the input, so that they are consistent with the output [12]. In this study, the appropriate pedagogical elements of the educational system are in accordance with the developed model of open and massive online courses, representing its clear structure. It is possible to distinguish the elements related to the developed model of massive open online courses, which can improve digital literacy skills.

Correlation of theories of MOOCs with the development of the SDL MOOCs model. MOOCs are the use of distance learning technology and open online learning innovation (open education) [21] as components of the developed massive open online courses model. The primary objective thereof is to accommodate a number of users with no limitation of age and knowledge background. The system also allows learners all over the world to access any subjects based on their own aptitudes or interest [4] free of charge, regardless of what institutions they belong to. In this research, the appropriate instructional elements of massive open online courses were studied and used as guidelines to develop the massive open online courses model herein. There are 4 elements [13-15], i.e., (1) M: Massive refers to something very large, (2) O: Open refers to free admission, (3) O: Online refers to online working, and (4) Cs: Courses refer to a variety of courses. It is also concerning a study of fundamental principles of the massive open online courses so that the massive open online courses model to be developed herein could have the clear-cut elements and approaches and could efficiently promote the learning society by making use of instructional technology and learning innovation.

Correlation of theories of SDL with the development of the SDL MOOCs model. The SDL is a learning model that encourages learners to be responsible for developing their own learning plans based on their skills and abilities. Learners will seek knowledge and experiences based on their needs, identify their learning goals, make their learning plans, complete the learning activities in the learning plans, and self-assess their learning to achieve their goals [6]. In this research, the process of teaching with self-directed learning [16] was studied and synthesized into steps to be used in 
the process of teaching with self-directed learning to enhance digital literacy skills (SDL process), which was then applied in the development of the SDL MOOCs model.

Correlation of theories of digital literacy skills with the development of the SDL MOOCs model. Digital literacy skills are considered one of the 21 st century learning skills that promote understanding of how to use digital technology, so that learners can have lifelong learning, leading to a learning society that can use information technology. In this study, the correlation of desired characteristics of digital literacy skills [18, 19], related to relevant theories, was considered and used as an outcome of the developed model of MOOCs.

Correlation of theories of achievement and satisfaction with the development of the SDL MOOCs model. The learning outcome is the result of the learning process in the developed model of massive open online courses. It is the result of learners' knowledge, represented as a score or level of competence derived from tests or exercises [22]. Learning success is, therefore, an important assessment that can confirm learners' knowledge and abilities obtained from lessons. Satisfaction is the result in the form of attitudes and feelings that appear when the results are achieved as expected. In this research, the result obtained during the learning process of the developed massive open online course model (SDL Process) was studied and used as feedback to improve the effectiveness of the developed MOOC model. With reference to the synthesis of theories and the correlation of relevant theories above, the conceptual framework for this research was derived as shown in Figure 2.

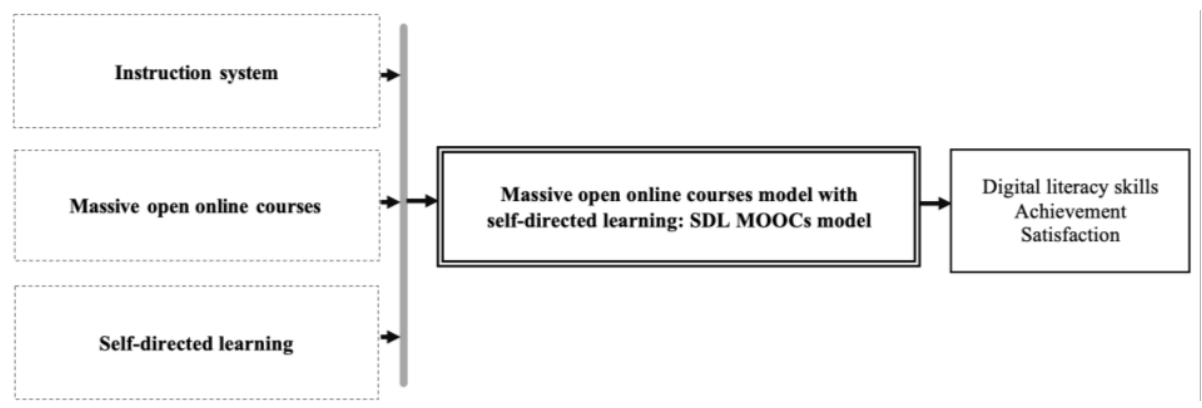

Fig. 2. Conceptual framework of the SDL MOOCs model

\subsection{Results of the development of the massive open online courses model with self-directed learning to enhance digital literacy skills}

In developing the model of massive open online courses with self-directed learning to enhance digital literacy skills (SDL MOOCs model), the researcher relied on the concepts of instructional systems design that consist of systematic elements, processes, and steps (systems approach), combined with the pedagogical elements of MOOCs, as shown in Figure 3. 


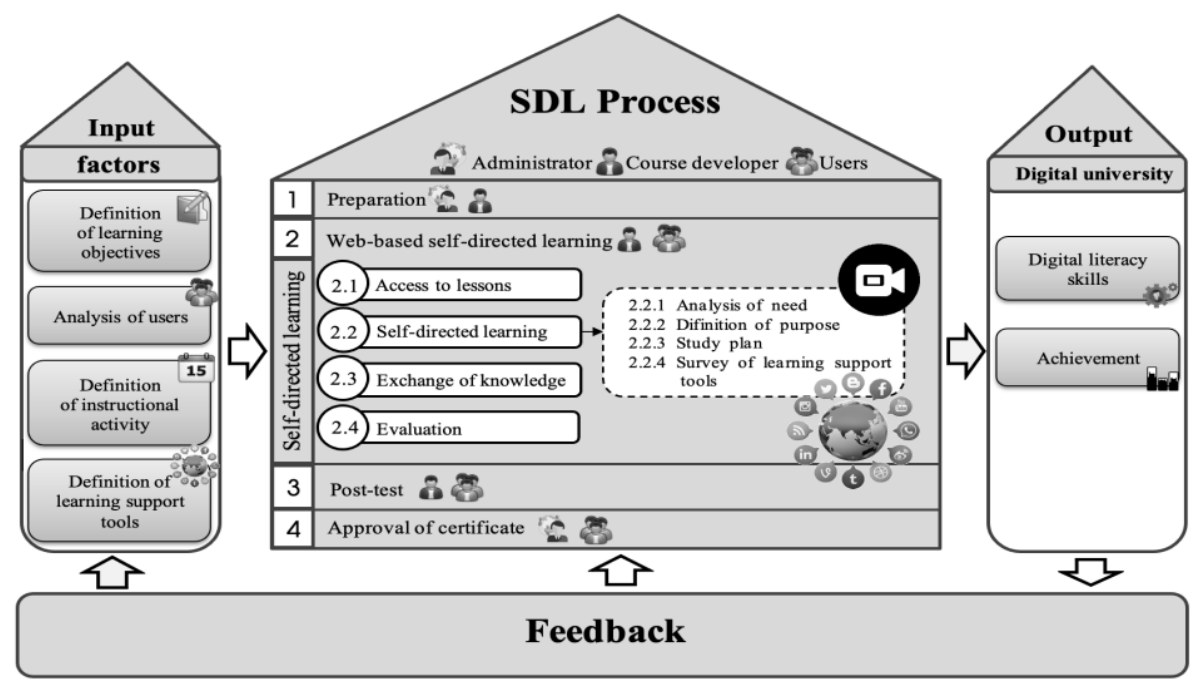

Fig. 3. The SDL MOOCs model to enhance digital literacy skills

According to figure 3, the massive open online courses model with self-directed learning consists of 4 main elements with the following details.

1. Input factors, i.e., definition of learning objectives, analysis of users, definition of instructional activity, and definition of learning support tools, can be summarized as below:

- Definition of learning objectives: It is intended to find out the expected learning behaviors by means of evaluation after studying specific contents of the lessons.

- Analysis of users: It is a kind of basic data analysis of users, such basic knowledge, basic skills, learning methods, interests, aptitudes, learning objectives, etc. The objective of this section is to design a learning system that is suitable and meets the needs of users.

- Definition of instructional activity: The management of suitable activities is an important element that enables users to participate in learning and interact with the developed lessons and systems. Thereby, the said activity can be applied to develop their own learning process.

- Definition of learning support tools: Learning support tool is believed to encourage users to achieve their desired learning goals.

2. Instructional processes (SDL Process), i.e., preparation, web-based self-directed learning, post-test, and approval of certificate, can be explained in detail as follows:

- Preparation: This stage consists of 3 steps, i.e., system introduction, sign up to the system, and selection of subjects (with/without cost)

- Web-based self-directed learning: It is a kind of learning stage that allows the learners to be responsible for setting their own learning plans based on their skills and competencies. Basically, the web-based self-directed learning is on the basis of 
learning plans related to the learners' experiences, and the learners shall control this process by themselves. Thereby, this stage includes 4 steps, i.e., (1) access to lessons, in which users are encouraged and motivated to become interested in the courses, starting with introduction to course descriptions, course contents, and the goals to accomplish at the end of the study, (2) self-directed learning, which is concerning the steps of studying the contents of the lessons and conducting instructional activities according to the self-directed learning process. The users shall participate in learning and interacting through a variety of learning support tools such as web forums, social media, etc., (3) exchange of knowledge, which focuses on encouraging the users to have interaction to brainstorm and exchange knowledge in order to bring about new ideas, and (4) evaluation.

- Post-test: This stage is concerning a procedure to measure learning achievement of the users after studying all the provided contents and all the activities in the course syllabus. The said learning achievement is measured by taking multiple-choice tests, open-ended exams, or other formats of tests, depending on the discretion of course developers. Also, the evaluation criteria for a certificate are set up by the course developers as well.

- Approval of certificate: This is the process of verifying the information by considering whether the users are qualified according to the criteria set by the course developers or not. In case the specified conditions are met, the system will approve that the users are eligible to receive a certificate.

3. Output, i.e., digital literacy skills, achievement, and satisfaction, includes the following details:

- Digital Literacy Skills: This refers to the skills of understanding and application of digital technology that encourage learners to achieve lifelong learning, which can lead to learning society by making use of such information technology as Media Literacy, Technology Literacy, Information Literacy, Visual Literacy, Communication Literacy, and Social Literacy.

- Achievement: This means the learning achievement that the learners will receive on the condition that they must be qualified as to the criteria provided by the course developers.

- Satisfaction: It refers to the satisfaction of users towards the learning through the developed SDL MOOCs model.

4. Feedback: It is the use of data that are derived from the output stage as feedback data. The objective of feedback is to improve the learning process and input factors so that they shall have more suitability and more efficiency. 
Paper-Massive Open Online Courses Model with Self-directed Learning to Enhance Digital Literacy...

Table 1. Results of the synthesis of desired characteristics from digital literacy skills $[18,19]$

\begin{tabular}{|c|c|c|}
\hline Digital literacy & Digital literacy skills & Desired characteristics \\
\hline \multirow{6}{*}{$\begin{array}{l}\text { Digital Literacy is con- } \\
\text { sidered one of the life } \\
\text { skills which are associ- } \\
\text { ated with one another. } \\
\text { The said skills include } \\
\text { Media Literacy, Tech- } \\
\text { nology Literacy, Infor- } \\
\text { mation Literacy, Vis- } \\
\text { ual Literacy, Commu- } \\
\text { nication Literacy, and } \\
\text { Social Literacy. }\end{array}$} & 1. Media literacy & $\begin{array}{l}\text { The results reflect the ability of learners in terms of access, } \\
\text { analysis, and production of media based on the under- } \\
\text { standing, and communication of ideas in an effective man- } \\
\text { ner. }\end{array}$ \\
\hline & 2. Technology literacy & $\begin{array}{l}\text { The results represent the expertise of using technology in } \\
\text { learning and communication. }\end{array}$ \\
\hline & 3. Information literacy & $\begin{array}{l}\text { The results reflect the ability to search the required infor- } \\
\text { mation online, to select appropriate information, and to } \\
\text { use information for data retrieval. }\end{array}$ \\
\hline & 4. Visual literacy & $\begin{array}{l}\text { It is a reflection of learners' ability to understand and in- } \\
\text { terpret what they view, including analysis, learning, and } \\
\text { showing their opinions. }\end{array}$ \\
\hline & $\begin{array}{l}\text { 5. Communication } \\
\text { literacy }\end{array}$ & $\begin{array}{l}\text { It reflects the ability to exchange knowledge with others in } \\
\text { the society via social media or online learning materials. }\end{array}$ \\
\hline & 6. Social literacy & $\begin{array}{l}\text { It is a reflection of ability to work hand in hand with oth- } \\
\text { ers in order to achieve the goals. }\end{array}$ \\
\hline
\end{tabular}

\subsection{Results of the development of instructional processes with self-directed learning to enhance digital literacy skills}

In the teaching processes with self-directed learning to improve digital literacy skills (SDL process), the researcher defined the learning stages in the SDL MOOCs model, which was synthesized from the self-directed learning process [6], as shown in Figure 4.

Figure 4 represents the instructional processes with self-directed learning to enhance digital literacy skills (SDL Process). Thereby, the researcher determined the following 4 learning stages within the developed massive open online courses model, including (1) Preparation, which consists of 3 steps, i.e., system introduction, sign up to the system, and selection of subjects (with/without cost), (2) Web-based self-directed learning, in which the researcher applied the theories of self-directed learning to define learning steps in the developed massive open online courses model. The said learning steps include access to lessons, self-directed learning, exchange of knowledge, and evaluation. At this stage, the researcher also performed a contextual analysis to determine the elements of instructional management to be further used to support the web-based selfdirected learning, i.e., learning objectives, contents, roles of course developer, roles of users, instructional activity, and learning support tools, (3) Post-test, which is designated to measure learning achievement after the users have completed all of the required course and activities, and (4) Approval of certificate. 


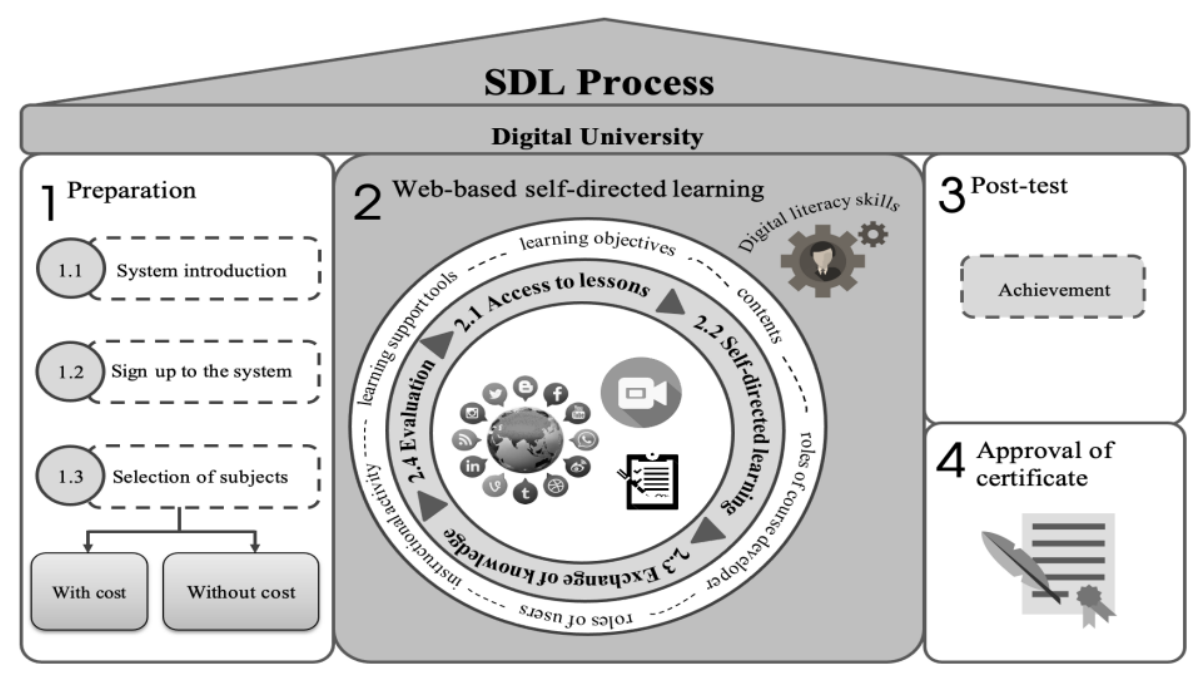

Fig. 4. Instructional processes with self-directed learning to enhance digital literacy skills

\subsection{Results of evaluation on the suitability of the development of the massive open online courses model and instructional processes with self-directed learning to enhance digital literacy skills}

The study of suitability of the development of the massive open online courses model with self-directed learning to enhance digital literacy skills (SDL MOOCs model). The study of suitability herein was conducted by the 15 experts and the criteria for data analysis (see Table 2) are on the basis of interpretation of Kanasutra [20].

According to the development of the SDL MOOCs model, the results are detailed in Table 3. In reference to Table 3, it is found that the overall suitability of the development of the SDL MOOCs model (overall elements) is at very high level (Mean $=4.93$, $\mathrm{SD}=0.30$ ). Accordingly, this can probably be concluded that the SDL MOOCs model has all required elements, and it can be employed as a guideline to develop the massive open online courses that can encourage the learners to initiate their self-learning.

Table 2. Range of average scores and interpretation of results

\begin{tabular}{|l|l|}
\hline Average score range & \multicolumn{1}{|c|}{ Interpretation of results } \\
\hline $4.50-5.00$ & Very high level of suitability \\
\hline $3.50-4.49$ & High level of suitability \\
\hline $2.50-3.49$ & Average level of suitability \\
\hline $1.50-2.49$ & Low level of suitability \\
\hline $1.00-1.49$ & Very low level of suitability \\
\hline
\end{tabular}


Paper-Massive Open Online Courses Model with Self-directed Learning to Enhance Digital Literacy...

Table 3. Results of the SDL MOOCs model development adequacy assessment model (overall elements)

\begin{tabular}{|l|c|c|c|}
\hline \multirow{2}{*}{ Description } & \multicolumn{2}{|c|}{ Results } & \multirow{2}{*}{ Interpretation } \\
\cline { 2 - 3 } & Mean & SD & \\
\hline $\begin{array}{l}\text { 1. The massive open online courses model complies with fun- } \\
\text { damental concepts used to develop the instructional system. }\end{array}$ & 4.93 & 0.26 & \multirow{2}{*}{ Very high } \\
\hline $\begin{array}{l}\text { 2. The range of coverage of elements in the massive open } \\
\text { online courses model conforms to the main elements of the in- } \\
\text { structional system. }\end{array}$ & 4.80 & 0.56 & \multirow{2}{*}{ Very high } \\
\hline $\begin{array}{l}\text { 3. The organization of elements in the design of the massive } \\
\text { open online courses model is clear with continuity. }\end{array}$ & 4.93 & 0.26 & \multirow{2}{*}{ Very high } \\
\hline $\begin{array}{l}\text { 4. The organization of elements in the design of the massive } \\
\text { open online courses model is suitable and easy to understand. }\end{array}$ & 5.00 & 0.00 & \multirow{2}{*}{ Very high } \\
\hline $\begin{array}{l}\text { 5. The overall elements in the massive open online courses } \\
\text { model are complete, covering all requirements and complying } \\
\text { with the objectives of this research. }\end{array}$ & 5.00 & 0.00 & \multirow{2}{*}{ Very high } \\
\hline Overall & 4.93 & 0.30 & \multirow{2}{*}{ Very high } \\
\hline
\end{tabular}

Referring to Table 4, it is evident that the overall suitability of the development of the SDL MOOCs model is at very high level (Mean $=4.91$, SD =0.31). It can be summarized the SDL MOOCs model can be applied as a guideline to further develop the massive open online courses, which can be used as an effective tool for learners to promote their self-learning. This is in line with the research of Chatwattana and Nilsook [23], who said that the design of concepts applied the principle of instructional system, and the principle of e-learning design can be support learning in students.

Table 4. Results of evaluation on suitability of the development of the SDL MOOCs model

\begin{tabular}{|l|c|c|c|c|}
\hline \multirow{2}{*}{ Description } & \multicolumn{2}{|c|}{ Results } & \multirow{2}{*}{ Interpretation } \\
\cline { 3 - 4 } & Mean & $\boldsymbol{S D}$ & \\
\hline \multirow{3}{*}{ Input factors } & Definition of learning objectives & 4.93 & 0.26 & \multirow{2}{*}{ Very high } \\
& Analysis of user & 4.93 & 0.26 & Very high \\
& Definition of instructional activity & 4.93 & 0.26 & Very high \\
& Definition of learning support tools & 4.87 & 0.35 & Very high \\
\hline \multirow{2}{*}{ Instructional pro- } & Preparation & 4.93 & 0.26 & Very high \\
cesses & Web-based self-directed learning & 4.87 & 0.35 & Very high \\
(SDL Process) & Post-test & 4.93 & 0.26 & Very high \\
& Approval of certificate & 4.87 & 0.35 & Very high \\
\hline \multirow{2}{*}{ Output } & Digital literacy skills & 4.80 & 0.41 & Very high \\
& Achievement & 5.00 & 0.00 & Very high \\
\hline \multirow{2}{*}{ Feedback } & Satisfaction & 4.93 & 0.26 & Very high \\
\hline Overall & Achievement scores & 5.00 & 0.00 & Very high \\
\hline
\end{tabular}

According to Table 5, it is obvious that the overall suitability of the development of instructional processes with self-directed learning to enhance digital literacy skills is at very high level $(\mathrm{Mean}=4.91, \mathrm{SD}=0.29)$. It can be summarized that the instructional 
processes with self-directed learning can promote the learners to have more self-learning experiences, more digital literacy skills, and more achievement. This is in line with the research of Kateryna et.al [24], who said that the digital literacy can be used to communicate and solve problems for effective and creative self-realization in education, work, and society. It is also consistent with the research of Gamage et al. [25], saying that the application of interactivity and collaboration in their instructional design can promote skills in learning. In addition, it is in compliance with the research of Wajeesiri [26], saying that the application of self-directed learning process to design an instructional model can promote analytical thinking and meanwhile increase learning achievement.

Table 5. Results of evaluation on suitability of the development of instructional processes with self-directed learning to enhance digital literacy skills

\begin{tabular}{|l|c|c|c|c|}
\hline \multirow{2}{*}{ Description } & \multicolumn{2}{|c|}{ Results } & \multirow{2}{*}{ Interpretation } \\
\cline { 3 - 4 } & & Mean & $\boldsymbol{S D}$ & \\
\hline \multirow{3}{*}{ Preparation } & System introduction & 4.93 & 0.26 & Very high \\
& Sign up to the system & 4.93 & 0.26 & Very high \\
& Selection of subjects & 4.87 & 0.35 & Very high \\
\hline \multirow{3}{*}{ Web-based self-directed } & Access to lessons & 4.93 & 0.26 & Very high \\
learning & Self-directed learning & 4.87 & 0.35 & Very high \\
& Exchange of knowledge & 4.93 & 0.26 & Very high \\
& Evaluation & 4.93 & 0.26 & Very high \\
\hline Post-test & & 4.93 & 0.26 & Very high \\
\hline Approval of certificate & & 4.87 & 0.35 & Very high \\
\hline Overall & & 4.91 & 0.29 & Very high \\
\hline
\end{tabular}

Table 6 shows that the overall suitability of the SDL MOOCs model in terms of practical use is at very high level (Mean $=4.95, \mathrm{SD}=0.22$ ). This can be concluded that the massive open online courses model with self-directed learning has suitable elements, stages, and processes. Also, the model can be applied as a guideline to further develop the massive open online courses with self-directed learning in order to promote the learners to initiate self-learning in digital universities, while enhancing their digital literacy skills and achievement in an efficient manner. According to the summary of results above, this research is compliant with that of Tan, Yu and Gong [27], who mentioned that MOOCs are a new form of education that can lead to the reform of higher education system, initiating the enhancement of instruction quality in universities. It is also consistent with the research of Anisimova, Ganeeva and Sharafeeva [28], who said digital skills are practical and vital to the real life. These skills can promote the development of competency and creativity, and can also generate self-confidence. 
Paper-Massive Open Online Courses Model with Self-directed Learning to Enhance Digital Literacy...

Table 6. Results of evaluation on suitability of the SDL MOOCs model in terms of practical use

\begin{tabular}{|l|c|c|c|}
\hline \multirow{2}{*}{ Description } & \multicolumn{2}{|c|}{ Results } & \multirow{2}{*}{ Interpretation } \\
\cline { 2 - 3 } & Mean & SD & \\
\hline $\begin{array}{l}\text { 1. Suitability of the massive open online courses model to en- } \\
\text { hance digital literacy skills. }\end{array}$ & 5.00 & 0.00 & Very high \\
\hline $\begin{array}{l}\text { 2. Suitability of stages and processes in self-directed learning } \\
\text { to enhance digital literacy skills. }\end{array}$ & 4.93 & 0.26 & Very high \\
\hline $\begin{array}{l}\text { 3. Possibility of the massive open online courses model to be } \\
\text { used as a guideline to develop the system of massive open } \\
\text { online courses (SDL MOOCs System). }\end{array}$ & 5.00 & 0.00 & Very high \\
\hline $\begin{array}{l}\text { 4. Possibility of the massive open online courses model for } \\
\text { practical use. }\end{array}$ & 4.87 & 0.35 & Very high \\
\hline Overall & 4.95 & 0.22 & Very high \\
\hline
\end{tabular}

\section{Conclusions}

The massive open online courses model with self-directed learning to enhance digital literacy skills (SDL MOOCs model) is considered a tool to promote learning outside the classroom for learners in the digital age. The concept is based on the combination of new technologies and teaching methods with the aim of creating new ideas and innovations that can promote learning among modern learners, and meanwhile can respond directly to their learning experiences. The model consists of 4 main elements: (1) Input factors, i.e., definition of learning objectives, analysis of users, definition of instructional activity, and definition of learning support tools, (2) Instructional processes (SDL Process), which consists of 4 steps: preparation, web-based self-directed learning, post-test, and approval of certificate, (3) Output, i.e., digital literacy skills, achievement, and satisfaction, and (4) Feedback, i.e., opinions of experts and achievement scores.

The suitability of the SDL MOOCs model was assessed by 15 experts. The results of this research show that (1) the suitability of the development of the SDL MOOCs model (overall elements) is at very high level (Mean $=4.93, \mathrm{SD}=0.30)$, (2) the suitability of the development of the SDL MOOCs model is at very high level (Mean $=4.91$, $\mathrm{SD}=0.31)$, (3) the suitability of the development of SDL Process is at very high level (Mean $=4.91, \mathrm{SD}=0.29$ ), and (4) the suitability in terms of practical use of the development of the SDL MOOCs model is at very high level (Mean $=4.95, \mathrm{SD}=0.22$ ).

This research can be applied as a guideline to design and develop massive open online courses that can promote learning among learners and generate self-development, satisfying student-centered learning policies and lifelong learning in Education 4.0. In addition, this can lead to a learning society in which the concepts, elements, and processes of self-directed learning are used as guidelines for designing teaching processes in open and massive online courses, encouraging learners to have learning experiences, have skills and abilities to implement their own learning plans, and be able to self-assess. At the same time, teaching activities are provided to promote learning and interaction among learners via social media networks, which can enable learners to have more digital literacy and learning achievements. 
Paper-Massive Open Online Courses Model with Self-directed Learning to Enhance Digital Literacy...

\section{Acknowledgment}

This research was funded by the College of Industrial Technology, King Mongkut's University of Technology North Bangkok (Grant No. Res-CIT0265/2020).

\section{References}

[1] Qureshi, I. M., Khan, N., Raza, H., Imran, A., and Ismail, F. (2021). Digital Technologies in Education 4.0. Does it Enhance the Effectiveness of Learning? A Systematic Literature Review. International Journal of Interactive Mobile Technologies (iJIM), 15(4): 31-47. https://doi.org/10.3991/ijim.v15i04.20291

[2] Ministry of Higher Education, Science, Research and Innovation. (2018). [Online]. Background Thai MOOC. [cited 28 February 2020]. Available from: http://mooc. thaicyberu.go.th/about-us/\#.X9xhDi0RpN0

[3] Maneewan, S. (2018). Development of Instructional Model via MOOC Management System with Potential Learning Tools to Enhance Creative Problem Solving on Advertising Photography. Journal of Vocational and Technical Education, 9(16): 25-36.

[4] Institute for Innovative Learning, Mahidol University. (2018). [Online]. MOOC (Massive Open Online Courses). [cited 28 February 2020]. Available from: https://il.mahidol.ac.th/th/ i-Learning-Clinic

[5] Marrhich, A., Lafram, I., Berbiche, N., and Alami, E. J. (2020). A Khan Framework-Based Approach to Successful MOOCs Integration in the Academic Context. International Journal of Emerging Technologies in Learning (iJET), 15(12): 4-19. https://doi.org/10.3991/ ijet.v15i12.12929

[6] Chatwattana, P., and Phadungthin, R. (2019). Web-based virtual laboratory for the promotion of self-directed learning. Global Journal of Engineering Education, 21(2): 157-164.

[7] Kim, A. (2020). [Online]. Conflict of institutions Foreign Portfolio Investment as an Impetus for Legal Education Reform Korea. [cited 2 April 2021]. Available from: https://repository.tcu.edu/bitstream/handle/116099117/40330/Kim_Alexander-Honors_Project.pdf?

[8] Giang, N., Hai, P., Tu, N., and Tan, P. (2021). Exploring the Readiness for Digital Transformation in a Higher Education Institution towards Industrial Revolution 4.0. International Journal of Engineering Pedagogy (iJEP), 11(2): 4-24. https://doi.org/10.3991/ijep. $\underline{\mathrm{v} 11 \mathrm{i} 2.17515}$

[9] Karpati, A. (2011). [Online]. Digital literacy in education. [cited 15 March 2020]. Available from: http://unesdoc.unesco.org/images/0021/002144/214485e.pdf

[10] Khemmani, T. (2010). Science of Teaching: Knowledge of Efficient Learning Process Management. (13 ${ }^{\text {th }}$ Edn), Bangkok: Chulalongkorn University Press.

[11] Brahmawong, C. (1985). Unit 12: Instructional System Management. Textbook on Teaching Methodology Vol 8-15. Nonthaburi. Sukhothai Thammathirat Open University.

[12] Utranan, S. (1982). Systematic Instructional Management. Bangkok: Chulalongkorn University.

[13] Glance, D., Forsey, M. and Riley, M. (2013). The pedagogical foundations of massive open online coursess. First Monday, 18(5-6 May 2013). https://doi.org/10.5210/fm.v18i5.4350

[14] Ansah, H. R., Ezeh, V. O., Teck, S. T and Sorooshian, S. (2020). The Disruptive Power of Massive Open Online Course (MOOC). International Journal of Information and Education Technology, 10(1): 42-47. https://doi.org/10.18178/ijiet.2020.10.1.1337 
Paper-Massive Open Online Courses Model with Self-directed Learning to Enhance Digital Literacy...

[15] HRK. (2014). [Online]. The potential and problems of MOOCs MOOCs in the context of digital teaching. [cited 22 February 2021]. Available from: https://www.hrk.de/fileadmin/_migrated/content_uploads/MOOCs_EN.pdf

[16] Knowles, M. S., (1975). Self-directed Learning: A Guide for Learners and Teachers. New York: Association Press.

[17] Arpavate, W. and Bhangam, C. (2017). Educational Administration of Rajamangala University of Technology Phra Nakhon towards Digital University. Research from the budget of income (Institute Research) of Fiscal Year 2017. Faculty of Mass Communication Technology, Rajamangala University of Technology Phra Nakhon. https://doi.org/10.20319/ mijst.2017.32.598607

[18] National Science and Technology Development Agency (NSTDA). (2015). [Online]. Development of Education Materials for MOOCs from 6 Best practices. [cited 30 July 2020]. Available from: https://doi.org/10.32738/ceppm.201310.0040

[19] Neadsuebsai, P. and Karaked, N. (2017). Factors Affecting University Development into a Digital University. Research Report, Rajamangala University of Technology Phra Nakhon.

[20] Kanasutra, P. (1995). Statistics for Research in the Behavioral Sciences. Bangkok: Chulalongkorn University Press.

[21] Jacques, S., Ouahabi A. and Lequeu, T. (2020). Remote Knowledge Acquisition and Assessment during the COVID-19 Pandemic. International Journal of Engineering Pedagogy (iJEP), 10(6): 120-138. https://doi.org/10.3991/ijep.v10i6.16205

[22] Tienthong, M. (2005). Courseware design and development for CAI. 2nd Edition. Department of Computer Education, Faculty of Technical Education, King Mongkut's University of Technology North Bangkok.

[23] Chatwattana, P., and Nilsook, P. (2017). A Web-based Learning System using Project-based Learning and Imagineering. International Journal of Emerging Technologies in Learning (iJET), 12(5): 4-22. https://doi.org/10.3991/ijet.v12i05.6344

[24] Kateryna, A., Oleksandr, R., Mariia, T., Iryna, S., Evgen, K. and Anastasiia, L. (2020). Digital Literacy Development Trends in the Professional Environment. International Journal of Learning, Teaching and Educational Research, 19(7): 55-79. https://doi.org/10.26803/ijlter. $\underline{19.7 .4}$

[25] Gamage, D., Perera, I., and Fernando, S. (2020). MOOCs Lack Interactivity and Collaborativeness: Evaluating MOOC Platforms. International Journal of Engineering Pedagogy (iJEP), 10(2): 94-111. https://doi.org/10.3991/ijep.v10i2.11886

[26] Wajeesiri, K. (2010). The Development of Self-directed Learning on Web Model for Enhancing Analytical Thinking Ability and Learning Achievement of Primary Students. Degree of Doctor of Philosophy Program in Technical Education Technology, Graduate College, King Mongkut's University of Technology North Bangkok. https://doi.org/10.14416/j. $\underline{\text { fte. } 2016.12 .008}$

[27] Tan, M., Yu, P. and Gong, F. (2016). The development path of MOOCs for China's higher education and its applications in engineering and technology education. World Transactions on Engineering and Technology Education (WTE\&TE), 14(4): 525-530.

[28] Anisimova, T., Ganeeva, A., and Sharafeeva, L. (2021). Development of Digital Skills and Engineering Thinking in Students as Part of the Digital Summer Project. International Journal of Engineering Pedagogy (iJEP), 11(2): 69-81. https://doi.org/10.3991/ijep.v11i2.17215 
Paper-Massive Open Online Courses Model with Self-directed Learning to Enhance Digital Literacy...

\section{Author}

Pinanta Chatwattana is an associate professor at the College of Industrial Technology (CIT), King Mongkut's University of Technology North Bangkok (KMUTNB), Bangkok, Thailand, 10800. Her teaching experience includes design technology and instruction methodology, web programing, animation and multimedia technology. Her research interests include education technology, instruction technique, information and communication technology for education apply information and communication technology in computer education, and apply information and communication technology for instruction.

Article submitted 2021-03-05. Resubmitted 2021-04-06. Final acceptance 2021-04-08. Final version published as submitted by the author. 